\title{
The ovary of the bignose fanskate Sympterygia acuta Garman, 1877 (Chondrichthyes, Rajidae) in the Bahía Blanca estuary, Argentina: morphology and reproductive features
}

\author{
Díaz-Andrade, MC., Galíndez, E.* and Estecondo, $S$. \\ Laboratorio de Histología Animal, Departamento de Biología, \\ Bioquímica y Farmacia, Universidad Nacional del Sur - UNS, \\ San Juan 670, 8000, Bahía Blanca, Argentina \\ *e-mail: galíndez@criba.edu.ar
}

Received July 31, 2007 - Accepted September 10, 2007 - Distributed May 31, 2009

(With 13 figures)

\begin{abstract}
Chondrichthyes have become an important economic resource in recent years. In spite of this importance, there is little knowledge about their reproductive biology, especially of species from the south-western Atlantic. In this work, we study the morphology and histology of the ovary of Sympterygia acuta. The results show that oogonia were present only in the immature females (stage I of maturity scale), whereas specimens in stages II and III of maturity displayed oocytes in all developmental steps. The most important histological features that vary throughout oocyte development are the presence or absence of yolk, the number of types and layers of follicular cells and the degree of development of the thecae. Follicular cells are, at least, of two different types. Finally, a new point of view for the determination of maturity stages in the field based on the size of follicles is discussed.
\end{abstract}

Keywords: Chondrichthyes, folliculogenesis, maturity stage, reproductive biology, Sympterygia acuta.

\section{O ovário da bignose fanskate Sympterygia acuta Garman, 1877 (Chondrichthyes, Rajidae) no estuário de Bahía Blanca, Argentina: morfologia e características reprodutivas}

\begin{abstract}
Resumo
Os Chondrichthyes tornaram-se num importante recurso econômico nos últimos anos. Apesar da sua importância, é muito pouco o que se conhece da sua biologia reprodutiva, especialmente das espécies do Atlântico sul-ocidental. Neste trabalho, foi estudada a morfologia e histologia do ovário de Sympterygia acuta. Os resultados mostraram que as oogonias somente encontraram-se presentes nas fêmeas imaturas (fase I de escala de maturidade) e que os animais em estágio II e III de maturidade exibiram oocitos em todas as etapas de desenvolvimento. As características histológicas mais importantes que variam ao longo de desenvolvimento dos oocitos são a presença da suarda, o tipo e quantidade de celas foliculares e o grau do desenvolvimento do thecae. Existem pelo menos dois tipos de células foliculares. Finalmente se discute um novo ponto de vista para a determinação dos estágios de maturidade no campo, baseado no tamanho dos folículos.
\end{abstract}

Palavras-chave: Chondrichthyes, folliculogenesis, fase de maturidade, biologia reprodutiva, Sympterygia acuta.

\section{Introduction}

Chondrichthyes appeared on earth 400 million years ago. They constitute a diverse group in all aspects of lifestyle, particularly in their mode of reproduction (McEachran and Dunn, 1998). All modern chondrichthyans exhibit internal fertilization and specialized genital tracts adapted for uterine gestation (Tricas, 1980). They are either oviparous or viviparous with four modes of viviparity based on the source of nutrition for the developing embryo (Koob and Callard, 1991). In spite of this diversity in reproductive strategies, the group is characterized by low growth, an extensive period of gestation and a scarce number of large offspring, resulting in low reproductive potential (Hoenig and Gruber, 1990).

At least half of the Chondrichthyes belong to the order Rajiformes, being the Rajidae family the most important. All skates are oviparous producing large oocytes with considerable yolk supplies. They encapsulate the eggs in complex egg cases produced by the oviducal 
gland and lay them in muddy or sandy areas where they adhere to small pieces of rock, shell or seaweed. This egg case constitutes the only protection against pathogens or predators (Kormanik, 1993).

Sympterygia acuta is an endemic species of the Argentinean Province with a latitudinal distribution between $22^{\circ}$ and $43^{\circ} 20^{\prime} \mathrm{S}$ (De-Queiroz, 1995). It can be found from coastal waters to $188 \mathrm{~m}$ of depth (Meneses and Paesch, 2003), although it is caught mainly at $50 \mathrm{~m}$ of depth (Massa et al., 2004). The Bahía Blanca estuary is known for its use by fishes to mate and give birth (López-Cazorla, 1987). S. acuta is present in this estuary throughout the year, with an abundance peak from the middle spring to summer (Mabragaña et al., 2002) constituting an important economic resource (Massa et al., 2003). The UICN Red List for threatened species (2006) has included this species since 2004 considering it "vulnerable" (A2bd). Nevertheless, S. acuta, along with other skates and demersal sharks, is a common by-catch in the coastal and continental shelf bottom-trawl fisheries in the Argentine-Uruguayan Common Fishing Zone (Meneses and Paesch, 2003).

In spite of the evolutionary and economic importance of chondrichthyans, there are a scarce number of investigations with regards to the ovary structure and they have been conducted mainly in species from intensive fishing zones (Pratt, 1988; Hamlett et al., 1999; Hamlett and Koob, 1999; Prisco et al., 2001; 2002a,b; Stehmann, 2002; Storrie, 2004; Oddone et al., 2005). About the genus Sympterygia there are very few investigations and they treat mainly ecological features (Pires, 1987; De-Queiroz, 1984; 1995), parasitology (Romera, 1993; Tanzola et al., 1998) and some reproductive features (Mabragaña et al.; 2002, Oddone and Vooren, 2002; Oddone and Velasco, 2004; Galíndez and Estecondo, 2008).

The present work represents a contribution to the knowledge of the structure of the ovary of $S$. acuta, the features that characterize the different stages of folliculogenesis and some remarks on the reproductive biology of this commercially important and vulnerable species.

\section{Materials and Methods}

A total of 12 females of S. acuta were collected monthly by line fishing in the inner and medium zones of the Bahía Blanca estuary $\left(61^{\circ} 30^{\prime}-62^{\circ} 30^{\prime} \mathrm{W}\right.$ and $\left.38^{\circ} 45^{\prime}-39^{\circ} 30^{\prime} \mathrm{S}\right)$. This number of exemplars was considered appropriate due to the vulnerable status and the decline of its biomass in the stocks. The total length and disc width and length of each specimen were measured. Each animal was humanely terminated by blunt trauma to the cranium and then dissected. Once the ventral cavity was opened, the sexual maturity of the females was determined following the Braccini and Chiaramonte (2002) criteria. This standard technique, common on board, is more than simple but in agreement, in general terms, with that proposed by Stehmann (2002).
For each specimen, at least one ovary was cut in small pieces for histology and in six specimens one ovary was dissected in toto for follicular countdown. This material and small pieces of the liver were fixed in Bouin's fixative or formaldehyde $10 \%$ in seawater, dehydrated through a graded series of alcohols and embedded in paraffin wax. Then, 5-10 $\mu$ m-thick sections were stained by Masson's trichromic stain, haematoxylin-eosin, alcian blue technique at $2.5 \mathrm{pH}$ level, periodic acid Schiff reaction, Gomori technique for reticulum and orceine. Selected sections were photographed using an Olympus BX51 light microscope equipped with an Olympus C-7070 digital camera.

The ovaries fixed in toto were carefully opened and each oocyte inside was measured in millimetres using a SOMET calibre with a $1 / 20 \mathrm{~mm}$ precision. The data obtained was grouped at intervals of increasing amplitude to compensate the asymmetry of the variate.

A classification limit was identified macroscopically at $3.5 \mathrm{~mm}$ corresponding to the smaller size at which oocytes were yellow prior to the fixation. On the other hand, another limit was identified microscopically at $1 \mathrm{~mm}$, corresponding to the smaller size at which yolk was present in the ooplasm.

\section{Results}

Morphometric data of exemplars are shown in Table 1.

\subsection{Macroscopic description of the ovary}

Both ovaries were approximately of the same size, elongated and slightly compressed dorsoventrally. They were associated with the epigonal organ that extended beyond the length of the ovary. In a maturing or mature ovary (stages II and III of maturation scale) follicles of various sizes were present at any one time supported by loose connective tissue. Even though follicles were inter-

Table 1. Morphometric data of exemplars.

\begin{tabular}{lcccc}
\hline & $\begin{array}{c}\text { Maturity } \\
\text { stage } \\
\text { (macroscopic) }\end{array}$ & $\begin{array}{c}\text { Tot. } \\
\text { length } \\
\text { (cm) }\end{array}$ & $\begin{array}{c}\text { Disc } \\
\text { length } \\
\text { (cm) }\end{array}$ & $\begin{array}{c}\text { Disc } \\
\text { width } \\
\text { (cm) }\end{array}$ \\
\hline Sa 1 & III & 50.0 & 28.0 & 28.0 \\
Sa 2 & III & 54.0 & 28.0 & 29.0 \\
Sa 5 & III & 54.5 & 31.0 & 31.5 \\
Sa 6 & III & 53.5 & 28.0 & 29.0 \\
Sa 7 & III & 50.0 & 28.0 & 31.0 \\
Sa 8 & III & 58.0 & 30.0 & 33.0 \\
Sa 10 & III & 56.0 & 30.0 & 31.0 \\
Sa 11 & III & 56.6 & 30.0 & 31.0 \\
Sa 3 & II & 49.0 & 32.0 & 28.5 \\
Sa 4 & II & 50.0 & 32.0 & 29.0 \\
Sa 12 & II & 48.0 & 27.5 & 28.0 \\
Sa 9 & I & 31.0 & 17.0 & 22.0 \\
\hline
\end{tabular}


mingled in different degrees of maturation, an increase in size from cranial to caudal and from dorsal to ventral could be recognized externally.

\subsection{Microscopic description of the ovary}

In the immature specimen, the ovary appears as a small structure at the medial cranial side of the epigonal organ. As ovary development goes on, the epigonal organ withdraws and becomes restricted to a small posterior outline and the space between oocytes.

The ovary is surrounded by a folded simple columnar and ciliated germinative epithelium (Figure 1). Beneath the epithelium, there is a dense connective tissue with abundant reticular and collagen fibres and scarce elastic fibres. There are also abundant smooth muscular cells and blood vessels. There is no evidence of an ovarian matrix.

\subsection{Folliculogenesis}

Clusters of oogonia (Figure 2) were present only in the immature specimen (stage I) just beneath the germinative epithelium. Each germ cell $(\sim 20 \mu \mathrm{m})$ has an eosinophilic cytoplasm and a big euchromatic nucleus with an evident nucleolus.

Primordial follicles are surrounded by simple squamous follicular cells (Figure 3). At this stage a few thecal plane cells begun to differentiate. The oocyte shows a large nucleus containing a single nucleolus and lampbrush chromosomes. At this point of development, the zona pellucida appears as a diffuse and discontinuous structure. When follicles reach a diameter of approxi-

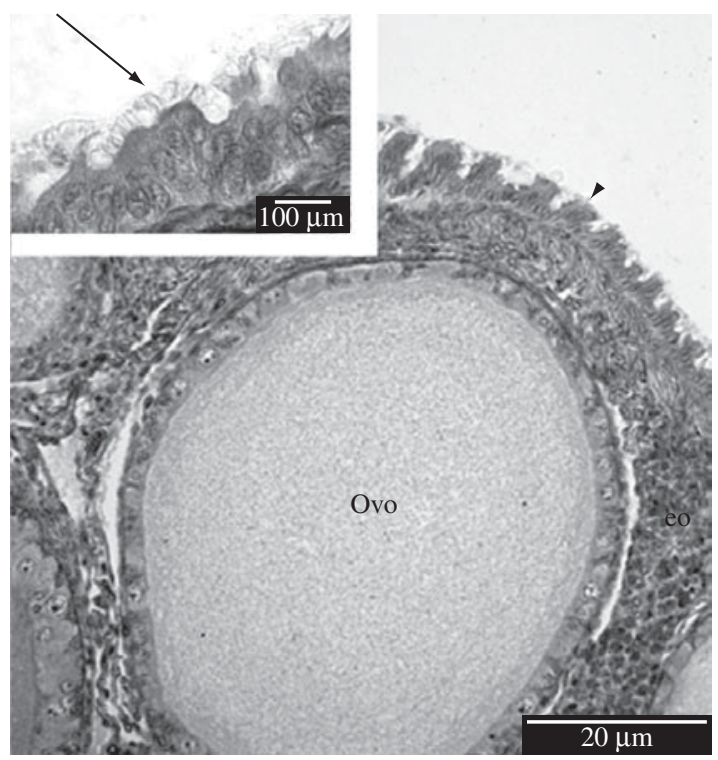

Figure 1. General view of the outer region of the ovary. Arrow head indicates the folded germinative epithelium; arrow is pointed in the ciliated epithelium; Ovo; oocyte; eo: epigonal organ intermingled with oocytes. Masson'sTrichromic stain. mately $55 \mu \mathrm{m}$, some enlarged globed-shaped cells appear between follicular cells.

At $\sim 180 \mu \mathrm{m}$ (primary follicles) follicular cells become cuboids and arrayed in one layer (Figure 4), between them there are a great number of the globed-shaped cells (Figure 5). The zona pellucida is a homogeneous hyaline smooth line of $2 \mu \mathrm{m}$ thick. The oocyte plasmalema folds densely against the zona pellucida and appears

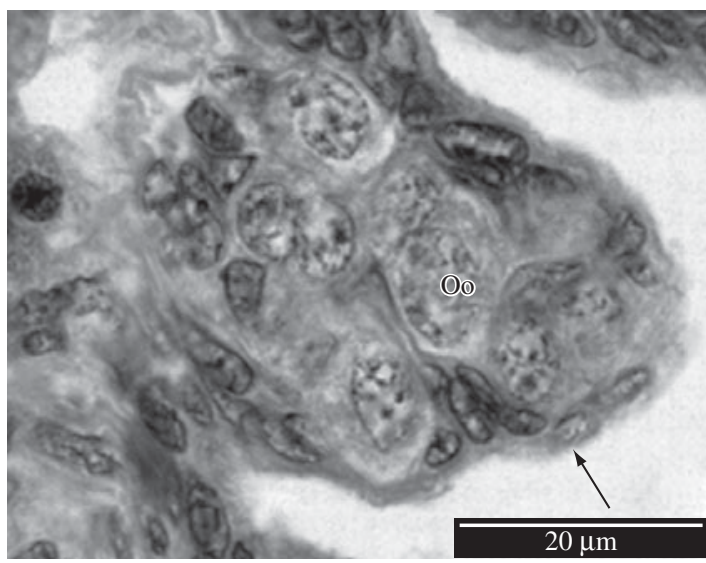

Figure 2. High power light image of a nest of oogonia. Arrows indicate the superficial epithelium; Oo: oogonia. Masson's Trichromic stain.

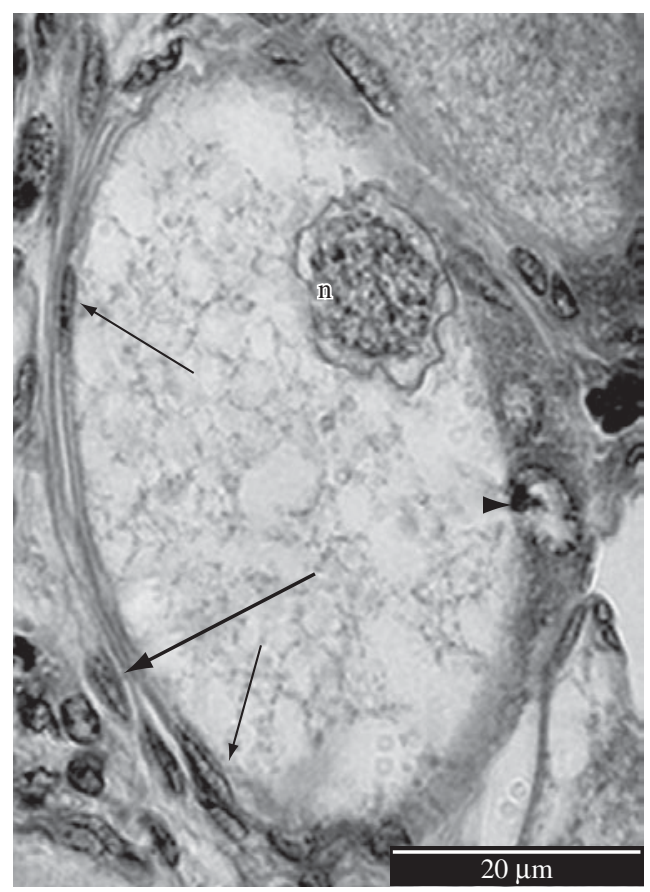

Figure 3. High power light image of a primordial oocyte. Observe the flat simple follicular epithelium (arrows), the beginning of an enlarged cell (arrow head) and the nucleus of a thecal cell (large arrow); n: nucleus. Masson's Trichromic stain. 
as a fluted refracting zone. At this point of development, the thecal layer begins to differentiate in an inner theca of squamous cells with plane euchromatic clear ended nucleus and eosinophilic cytoplasm, and an outer theca of squamous cells with plane, fusiform, heterochromatic nucleus and basophilic cytoplasm (Figure 5).

As the oocyte grows, follicular cells become columnar. When follicles reach $\sim 410 \mu \mathrm{m}$ diameter this epithelium begins to stratificate. Columnar cells are eosinophilic with heterochromatic nucleus. Between them, there are

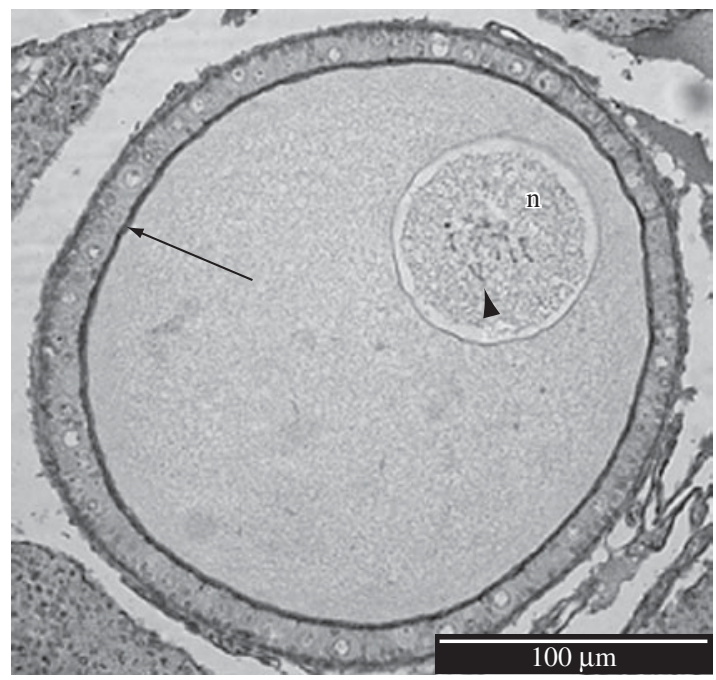

Figure 4. General view of a developing pre-vitellogenic oocyte (primary oocyte), arrows indicate the zona pellucida; $\mathrm{n}$ : nucleus; observe the follicular wall formed by a single layer of columnar cells and the lampbrush chromosomes (arrow head). PAS stain.

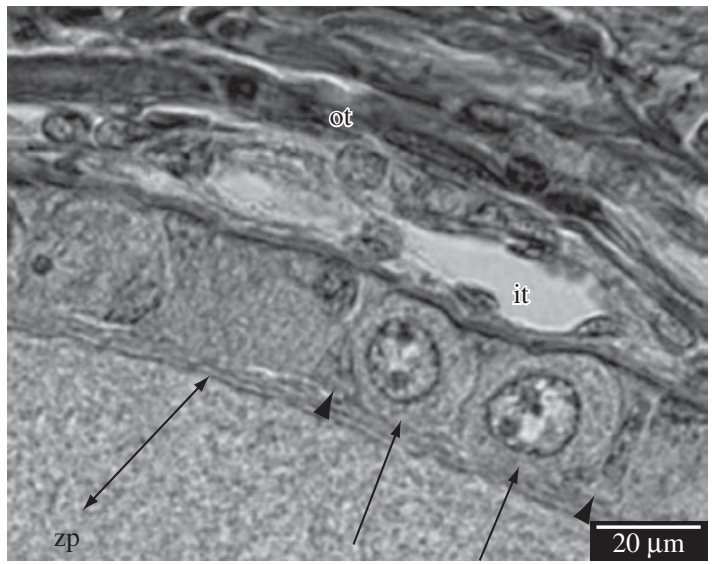

Figure 5. High power light image of a primary follicle; arrow heads indicate columnar cells; arrows show enlarged cells and double headed arrow depicts the zona pellucida (zp), observe the fine line close to the ooplasm (the fluted refracting zone); it: inner theca; ot: outer theca. Masson's Trichromic stain. enlarged basophilic cells with euchromatic nucleus, some of them with a pyriform-like shape (Figure 6 and 7). The cytoplasm of all cell types and the space between them are occupied by vesicles AB (+) and PAS (+) (Figure 7). At this point of development, thin projections establish between both types of follicular cells and ooplasm, crossing the zona pellucida (Figure 6). As a result, this region becomes thicker and irregular. The oocyte plasmalema shows no changes. Inner and outer thecae are clearly differentiable, with a high blood irrigation of the prime.

When follicles reach $\sim 1 \mathrm{~mm}$ of diameter, they begun to accumulate granules of yolk slightly stained. These granules increase in size as development continues to form finally elliptic plates (Figure 8).

From $\sim 7 \mathrm{~mm}$ of diameter both types of follicular cells form one layer and the zona pellucida becomes thinner with no projections. Inner theca was stratified and outer theca inconspicuous (Figure 9).

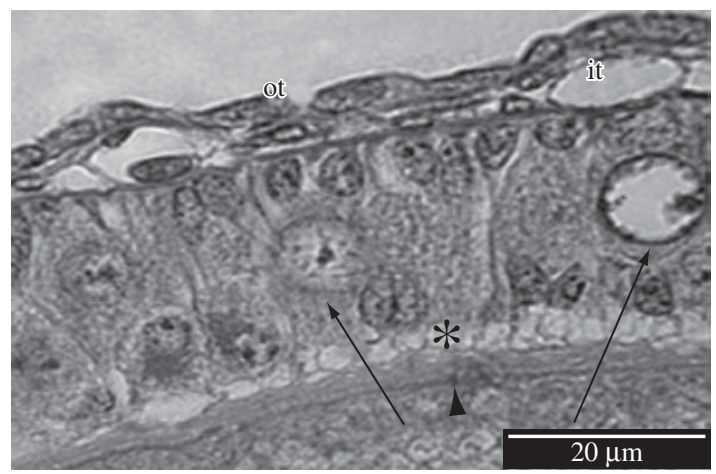

Figure 6. High power light image of a developing follicle wall (previtellogenic yet); asterisk indicates cytoplasmic projections between the oolema and follicular cells; arrows depict enlarged cells and arrow head the zona pellucida; it: inner theca; ot: outer theca. Masson's Trichromic stain.

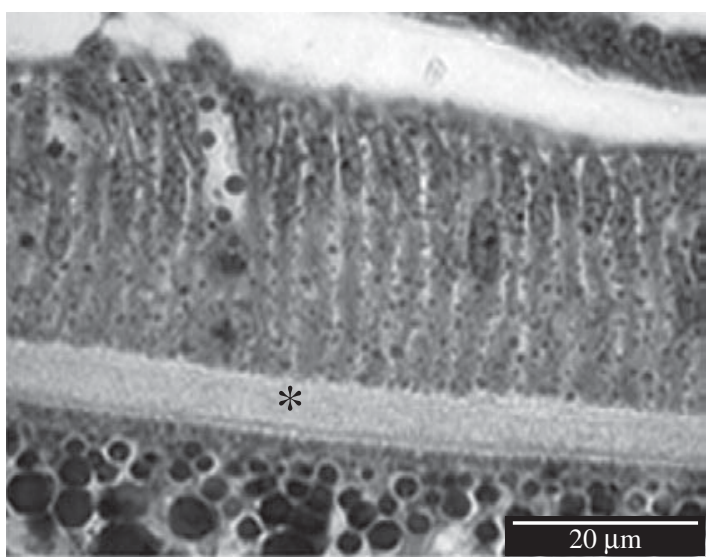

Figure 7. High magnification of the follicular wall. Observe the cells plenty of granules. Asterisk depicts the zona pellucida. Masson's Trichromic stain. 


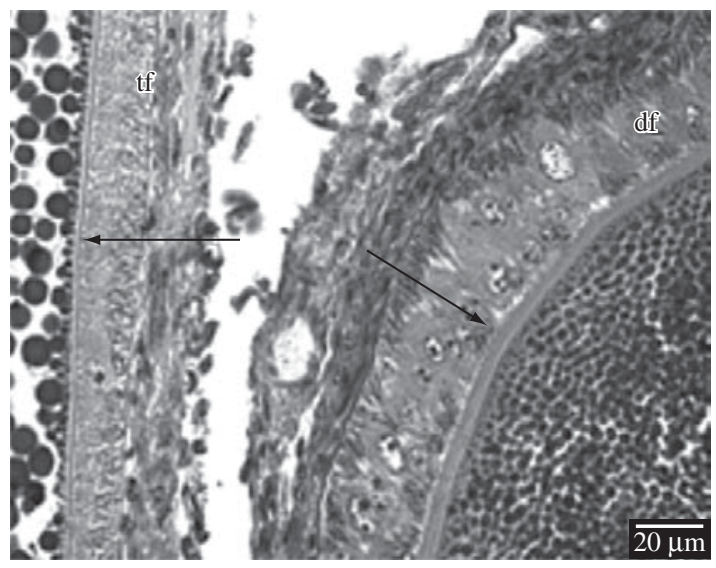

Figure 8. Detailed image of the follicular wall in a vitellogenic developing follicle (df, right) and in a term follicle (tf, left), arrows indicate the zona pellucida of both. Observe the difference in the size, shape and packaging of the vitellinic plates as well as the difference in the thickness of the wall. Masson's Trichromic stain.

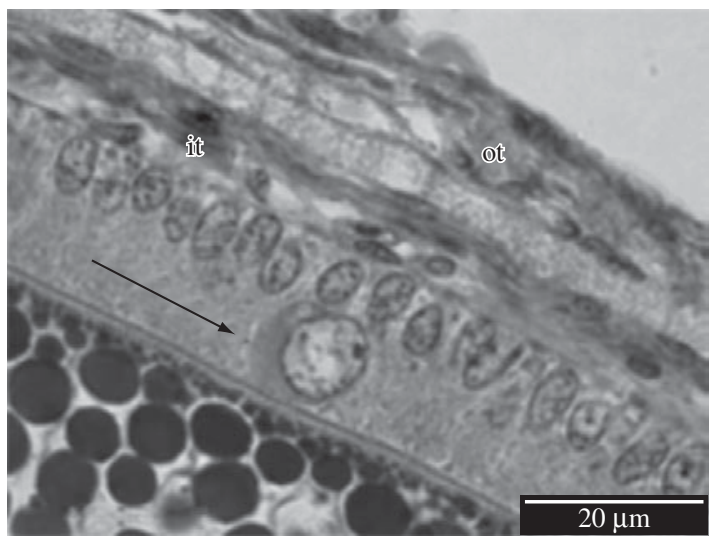

Figure 9. High power light image of an in term follicle; arrow indicates an enlarged cell; it: inner theca; ot: outer theca. Masson's Trichromic stain.

\subsection{Corpora lutea and liver}

Once the oocytes are released, follicular cells begin to degenerate. At first, they are tall eosinophilic cells with irregular apical surfaces (Figure 10). Between these cells there are few globe-shaped cells that apparently undergo in the first stages apoptosis (Figure 11). As Corpora lutea development goes on, dense connective tissue infiltrates this structure and follicular cells become cubic with a vacuolated aspect, probably due to the presence of lipids. At more advanced stages there is a dense conjunctive structure surrounding cellular fragments. The liver of females in the egg laying time is characterized by hepatocytes, plenty of drops of lipids and granules of glycogen (Figure 12).

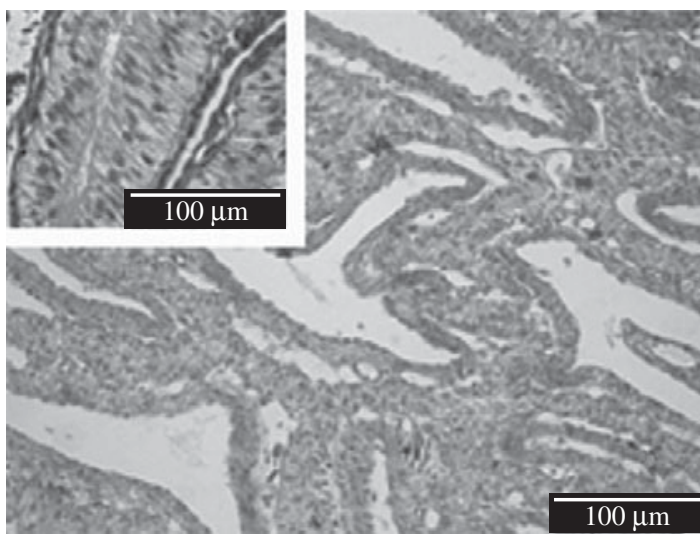

Figure 10. General view of a recent forming Corpora lutea.; Masson's Trichromic stain. Note the frayed surface of columnar cells. Masson's Trichromic stain.

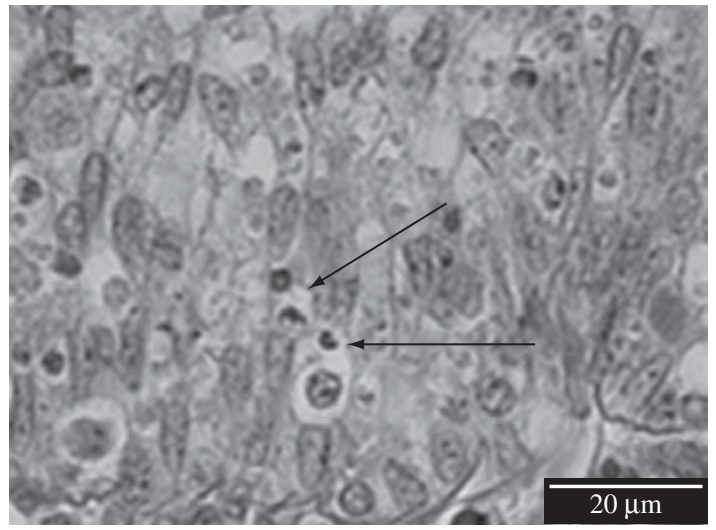

Figure 11. High power image of the cells of an incipient Corpora lutea. Arrows indicate the apoptotic figures, look the luteinic aspect of cells. Masson's Trichromic stain.

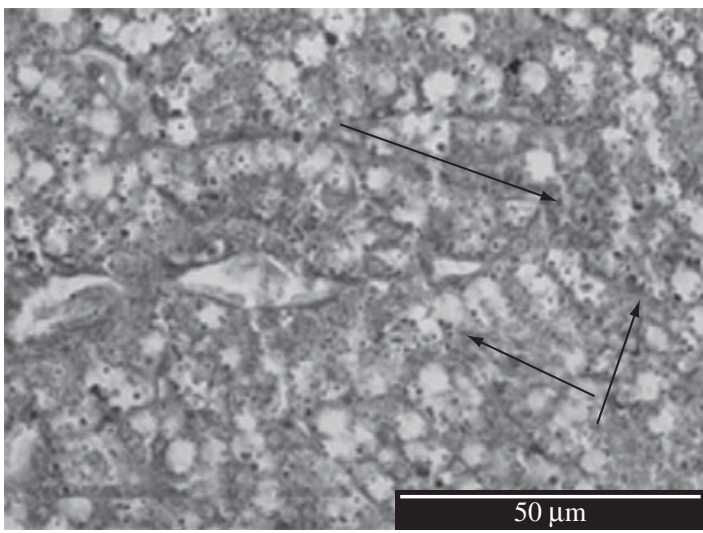

Figure 12. Middle power image of the same liver of the Figure 11. Observe the granules located inside cells and lateralized by the immersion fixation method. PAS stain. 


\subsection{Macroscopic follicles countdown}

Oocyte countdown results are shown in Figure 13 as a frequency histogram and Table 2 indicates the distribution of oocytes in each studied female. Results show that in the ovary only $34 \%$ of follicles are previtellogenic, whereas $49 \%$ of the follicles that are considered previtellogenic if we follow the present criteria of macroscopic identification are, in fact, vitellogenic. The remaining $17 \%$ correspond to yellow vitellogenic oocytes.

\section{Discussion}

Chondrichthyes are remotely related to osteichthyes and so, they have evolved in different ways (Moyle and Cech, 2000). One of the most important differ-

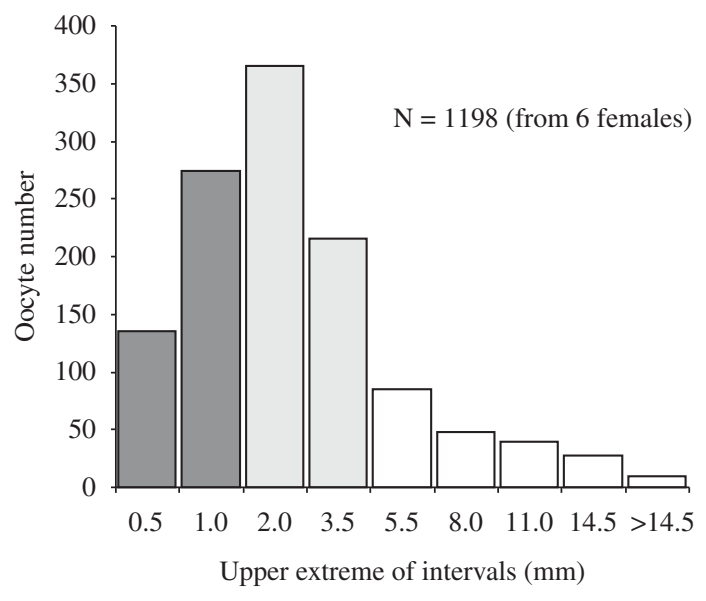

$\square$ Previtellogenic follicles

Vitellogenic follicles normally considered as previtellogenic at macroscopic level

Vitellogenic follicles

Figure 13. Frequency histogram of the oocyte countdown. ences between these groups is its reproductive strategy. Bonefishes depend on a high fecundity and specific ocean conditions to insure a high yield. On the other hand, cartilaginous fishes have long gestation periods, a high survival rate and a long-life after sexual maturation (Frisk et al., 2001), their energy is invested in the production of a scarce number of active and big enough offspring (Moyle and Cech, 2000). Sharks give birth one or twice a year and even once every two years, while rays can lay eggs all year long (Hoenig and Gruber, 1990). The bignose fanskate agrees with this reproductive pattern in some morphological and biological aspects. The relationship between the ovary and the epigonal organ during ontogeny is similar with that observed in other chondrichthyans species (Koob and Callard, 1991; Galíndez and Aggio, 2002; Storrie, 2004).

With regards to the microscopic characteristics, the ovary germinative epithelium of $S$. acuta represents a clearly different model from some studied cartilaginous fishes (Jezior and Hamlett, 1995; Hamlett et al., 1999) and is similar to those present in R. asterias (Barone et al., 2007), so a more detailed study is required.

During development, primordial germ cells originate at the endodermic layer of the yolk sac and migrate to the germinal ridge where they associate with follicular cells (Matova and Cooley, 2001). Prisco et al. (2001) have demonstrated in T. marmorata that oogenesis occurs early in development and continues even after birth. They observed clusters of oogonia and prefollicular oocytes only in newborn specimens and concluded that this feature was concordant with its low fecundity. Although oogonia were found only in young specimens in $S$. acuta this specie is able to release over 100 egg cases every setting (De-Queiroz, 1984; Oddone and Vooren, 2002), probably indicating an important number of offspring and marking a difference with the Torpedo model. In contrast to that observed in other oviparous species of chondrichthyans (Koob and Callard, 1991), the bignose fanskate does not present a pared disposition

Table 2. Distribution of oocytes in each studied female.

\begin{tabular}{crrrrrrrr}
\hline $\begin{array}{c}\text { Upper extreme of } \\
\text { oocyte diameters } \\
(\mathbf{m m})\end{array}$ & Sa 5 & Sa 8 & Sa 7 & Sa 6 & Sa 10 & Sa 11 & Total & \% \\
\hline 0.5 & 9 & 0 & 3 & 28 & 66 & 29 & 135 & 11.27 \\
1.0 & 44 & 0 & 27 & 8 & 137 & 58 & 274 & 22.87 \\
2.0 & 81 & 14 & 47 & 11 & 118 & 94 & 365 & 30.47 \\
3.5 & 34 & 22 & 29 & 28 & 55 & 47 & 215 & 17.95 \\
5.5 & 8 & 8 & 19 & 8 & 16 & 26 & 85 & 7.10 \\
8.0 & 1 & 9 & 4 & 5 & 18 & 11 & 48 & 4.01 \\
11.0 & 3 & 2 & 5 & 4 & 9 & 16 & 39 & 3.26 \\
14.5 & 5 & 2 & 6 & 5 & 8 & 1 & 27 & 2.25 \\
$>14.5$ & 5 & 0 & 3 & 2 & 0 & 0 & 10 & 0.83 \\
Total & 190 & 57 & 143 & 99 & 427 & 282 & 1198 & 100 \\
\hline
\end{tabular}


of follicles in the ovary. In spite of this, we consider that the number of ovaries that we used is low to support any conclusion.

In S. acuta the follicular wall consists in a follicular epithelium and a fibrous theca as in other Chondrichthyans (Guraya, 1978; 1986). Follicular cells begin as a simple squamous layer as in other fishes and non-mammalians (Guraya, 1978; Andreucetti et al., 1999; Prisco et al., 2002a,b; Storrie, 2004). Nevertheless, the dynamics of follicular wall is not common to all Elasmobranchs. During folliculogenesis the follicular wall of some shark species remains simple (Guraya, 1978; Storrie, 2004). However, as in other studied Rajiforms (Pratt, 1988), the follicular cells of $S$. acuta stratify but they return to a simple stage before ovulation. This observation is different from that observed in T. marmorata by Prisco et al. (2002a) and R. asterias (Barone et al., 2007), where follicular cells stratify but they never return to simple. In spite of this, there is not a consistent relationship in chondrichthyes between the changes on the follicular wall and the reproductive mode or even the follicular size.

One feature of Rajiforms is the presence of different follicular cell types (Guraya, 1978; Pratt, 1988). While Prisco et al. (2002a) and Barone et al., (2007) have differentiated, with electron microscopy, three cell types in T. marmorata and R. asterias, in this work we could distinguish clearly, with light microscopy, at least two types. Though we have observed enlarged pyriform-like cells of different shapes, we cannot assure that they constitute different cell types. Follicular cell projections are common in Chondrichthyes (Koob and Callard, 1991; Prisco et al., 2002a; Storrie, 2004). Hamlett et al., (1999) indicate digital projections of the small follicular cells, evident at optical level, and name them as transosomes, a term first used by Press (1964) for birds. On the other hand, Prisco et al. (2002a) describe the presence of intercellular bridges in T. mamorata and suggest their need for follicular cell differentiation, but they do not specify if they are seen only at an ultrastructural level. This pattern seems to be the same in $R$. asterias (Barone et al., 2007) and could probably be the case of the S. acuta. The presence of microvilli on the oocyte surface is common in no mammalian vertebrates (Guraya, 1978; Andreuccetti et al., 1999; Hamlett and Koob, 1999; Prisco et al., 2002a) and they are present in the bignose fanskate too. They may facilitate the transfer of material between the oocyte and surrounding tissues and the entry of nutrients and yolk precursors (Prisco el al., 2002b).

The zona pellucida is an acellular coat surrounding the oocyte of all vertebrates. It has not been determined conclusively for Chondrichthyans if it is produced by both the follicular epithelium and the oocyte, as in other animal groups (Storrie, 2004). This region has been described as formed by an inner striated zone due to the oocyte microvilli and epithelial cell processes (zona radiata) and an outer homogeneous zone (zona pellucida) (Ravaglia and Maggese, 2003). This is consistent with that observed in S. acuta. The thickness of the zona pellucida varies among vertebrates and this may be related to the reproductive strategy and ecology of the animal. The follicles of an oviparous pelagic teleost have thin structures whereas those of benthonic species are thick and complex to reduce abrasion and erosion (Ravaglia and Maggese, 2003). We have observed in S. acuta that the thickness of the zona pellucida varies along development, being thicker during the establishment of the follicular cell projections. With regards their composition, we have observed a positive reaction to PAS, indicating the presence of mucopolysaccharides, as in other species (Guraya, 1978; Koob and Callard, 1991; Storrie, 2004; Barone et al., 2007). However, the reactivity to the Alcian Blue at pH 2.5 observed in $S$. acuta seems to be the first record of the presence of acid mucopolysaccharides in this structure of Chondrichthyes.

Yolk production in cartilaginous fishes occurs by endogenous or exogenous mechanisms, or a combination of both (Prisco et al., 2002b). The presence of lipid and glycogen granules in the liver cells of adult bignose fanskate females indicates an active participation of this organ in the synthesis of reserve materials. Although the vitellogenesis in S. acuta may follow the model proposed by Prisco et al. (2002b), a more detailed physiological and ultrastructural study to confirm and complete our observations is necessary.

S. acuta has differentiated inner and outer thecae. There are many studies about the stereidogenic capacity of this tissue and there are differences among species referring to which the thecal layer has this capacity (Koob and Callard, 1999). In the bignose fanskate the outer theca has characteristics consistent with synthetical activity, and some other species that show this model are Squalus canicula (Guraya, 1978) and T. marmorata (Prisco et al., 2002a). The high blood irrigation of the inner theca in $S$. acuta may constitute an adaptation to increase the flow of nutrients to the oocyte and the delivery of products.

One important aspect of our work is the determination of the stage of sexual maturity of specimens. There are many ways to do this, the histology, sizing of oocytes, the external appearance of the ovary and gonadal indexes (West, 1990). The Braccini and Chiaramonte (2002) criteria is widely used in field work and it was our choice too. However, once the ovaries were studied at a microscopic level, we found a remarkable difference between the developmental stages of the oocytes determined in the laboratory and in the field, so that approximately $60 \%$ of the oocytes that were catalogued as previtellogenic following the macroscopic criteria were already committed to its reproductive function. This point is of particular interest because it could lead to bad interpretations of the reproductive potentialities and recovery rates of the species. Oddone and Velasco (2004) determined the size of sexual maturity in $S$. bonapartii using the presence of yellow oocytes as indicator of maturity. If in $S$. bonapartii follicles behave in the same way than in 
S. acuta, this could have lead to an overestimation of the female's maturity size.

Even though our observations are clearly different from those of Barone et al., 2007 in $R$. asterias, where microscopic and macroscopic classification are concordant, this aspect should be corroborated in other species because the size of the follicles, instead of its coloration, seems to be the most certain criteria to determine maturity, and this should be precise by histology. Although this makes generalizations difficult, it should be taken into account, mainly when a certain degree of accuracy is required.

Chondrichthyes clearly constitute a much conserved model with aspects of its ontogeny, development and reproduction very different from bonefishes, and certainly are much more vulnerable to over fishing (Paesch, 1999). Added to this, there is a growing number of chondrichthyan species classified as threatened by the UICN Red List (2006). Because of all this, it is necessary to increase our knowledge about its biology and specific reproductive characteristics, so that we might be able to implement effective management and preservation measures for this precious resource.

Acknowledgements - We thank the Prefectura Naval Bahía Blanca for their help with the samplings. This work was supported by the SGCyT-UNS, PGI:24/B100.

\section{References}

ANDREUCCETTI, P., IODICE, M., PRISCO, M. and GUALTERI, R., 1999. Intercellular bridges between granulosa cells and the oocyte in the elasmobranch Raja asterias. The Anatomical Record, vol. 255, no. 2, p. 180-187.

BARONE, MS., De-RANIERI, S., FABIANI, O., PIRONE, A. and SERENA, F., 2007. Gametogenesis and maturity stages scale of Raja asterias Delaroche, 1809 (Chondrichthyes, Rajidae) from the South Ligurina Sea. Hydrobiologia, vol. 580, no. 1, p. 245-254.

BRACCINI, JM. and CHIARAMONTE, GE., 2002. Biología de la raya Psammobatis extenta (Garman, 1913) (Batoidea: Rajidae). Revista Chilena de Historia Natural, vol. 75, p. $179-188$.

De-QUEIROZ, EL., 1984. Sympterygia acuta e Sympterygia bonapartei (Elasmobranchii: Rajiformes): hábitos alimentares e aspectos de reprodução na costa do Rio Grande do Sul. In Resumos do XI Congreso Brasileiro de Zoologia, Fevereiro 12-17. Belém: Universidade Federal do Pará. 207p.

1995. Coocorrência entre Sympterygia acuta Garman, 1877 e Sympterygia bonapartei Müller y Henle, 1841 (Elasmobranchii, Rajiformes) espécies endêmicas e simpátricas na plataforma continental do Rio Grande do Sul - Brasil. Revista Brasileira de Biologia = Brazilian Journal of Biology, vol. 55, no. 2, p. 293-303.

GALÍNDEZ, EJ. and AGGIO, MC., 2002. The granulopoietic organs of Mustelus schmitti (Chondrichthyes, Triakidae): a light and electron microscopic study. Revista Chilena de Anatomía, vol. 20 , no. 1 , p. $49-54$.
GALÍNDEZ, EJ. and ESTECONDO, S., 2008. Histological remarks of the oviduct and the oviducal gland of Sympterygia acuta Garmann, 1877. Revista Brasileira de Biologia = Brazilian Journal of Biology, vol. 68, no. 4. In press.

GURAYA, SS., 1978. Maturation of the follicular wall of nonmammalian vertebrates. In JONES, RE. (Ed.). The vertebrate ovary: comparative biology and evolution. London: Plenum Press. p. 261-329.

1986. The cell and molecular biology of fish oogenesis. Basel: Karger. 223p. Monographs in Developmental Biology.

HAMLETT, WC. and KOOB, TJ., 1999. Female reproductive system. In HAMLETT, WC. (Ed.). Sharks, skates and rays: the biology of elasmobranch fishes. Baltimore: The John Hopkins Univ. Press. p. 398-443.

HAMLETT, WC., JEZIOR, M. and SPIELER, R., 1999. Ultrastructural analysis of folliculogenesis in the ovary of the yellow spotted stingray. Urolophus jamaicensis. Annals of Anatomy, vol. 181, p. 159-172.

HOENIG, JM. and GRUBER, SH., 1990. Life-story patterns in the elasmobranchs: implications for fisheries management. In PRATT, HL.,GRUBER, SH. and TANIUCHI, T. (Eds.). Elasmobranchs as living resources: advances in the biology, ecology, systematic, and the status of the fisheries. NOAA Tech. Rep. NMFS, vol. 90, p. 1-16.

INTERNATIONAL UNION FOR CONSERVATION OF NATURE - IUCN, 2006. 2006 IUCN red list of threatened species. Gland: IUCN. Available from: <www.iucnredlist.org $>$. Access in: 1 de Fevereiro de 2007.

JEZIOR, M. and HAMLETT, WC., 1995. Ultrastructural organization of the ovarian follicle in the yellow spotted ray, Urolophus jamaicensis. Notre Dame Science Quarterly, vol. 34, no. 5 , p. 9

KOOB, TJ. and CALLARD, IP., 1991. Reproduction in female elasmobranchs. In KINNE, RKH. (Ed.). Comparative physiology. Basel: Karger. p. 155-209.

1999. Reproductive endocrinology of the little skate Raja erinacea and spiny dogfish, Squalus acanthias. Journal of Experimental Zoology, vol. 284, no. 5, p. 557-574.

KORMANIK, GA., 1993. Ionic and osmotic environment of developing elasmobranch embryos. Environmental Biology of Fishes, vol. 38, no. 1-3, p. 223-240.

LÓPEZ-CAZORLA, A., 1987. Contribución al conocimiento de la ictiofauna marina del área de Bahía Blanca. La plata; Buenos Aires: Facultad de Ciencias Naturales y Museo; Universidad Nacional de La Plata. Tese de Doutorado.

MABRAGAÑA, E., LUCIFORA, LO. and MASSA, AM., 2002. The reproductive ecology and abundance of Sympterygia bonapartii endemic to the south-west Atlantic. Journal of Fish Biology, vol. 60, no. 4, p. 951-967.

MASSA, A., HOZBOR, N. and COLONELlO, J., 2004. Situación actual y avances en el estudio de los peces cartilaginosos. Mar del Plata: INIDEP. Inf. Téc. Int. N ${ }^{\circ} 57$.

MASSA, AM., LUCIFORA, L. and HOZBOR, NM., 2003. Condríctios de la región costera bonaerense y uruguaya. In SÁNCHEZ, R. and BEZZI, S. (Eds). El Mar Argentino y sus recursos pesqueros: biología y evaluación del Estado de Explotación. Mar del Plata: Public. Esp.; INIDEP. 
MATOVA, N. and COOLEY, L., 2001. Comparative aspects of animal oogenesis. Dev. Biol., vol. 231, no. 2, p. 291-320.

McEACHRAN, JD. and DUNN, KA., 1998. Phylogenetic analysis of skates, a morphologically conservative clade of elasmobranchs (Chondrichthyes: Rajidae). Copeia, no. 2, p. 271-290.

MENESES, P. and PAESCH, L., 2003. Guía de campo para la identificación de peces cartilaginosos en el Río de la Plata y su frente oceánico. Frente Marítimo, vol. 19, Secc. B, p. 145-194.

MOYLE, PB. and CECH, JJ., 2000. Fishes: an introduction to ichthyology. 4 ed. New Jersey: Prentice-Hall.

ODDONE, MC. and VELASCO, G., 2004. Size at maturity of the smallnose fanskate Sympterygia bonapartii (Müller y Henle, 1841) (Pisces; Elasmobranchii, Rajidae) in the SW Atlantic. International Council for the Exploration of the Sea Journal of Marine Science, vol. 61, no. 2, p. 293-296.

ODDONE, MC. and VOOREN, CM., 2002. Egg-cases and size at hatching of Sympterygia acuta in the south-western Atlantic. Journal of Fish Biology, vol. 61, no. 3, p. 858-861.

ODDONE, MC., PAESCH, L. and NORBIS, W., 2005. Size al first sexual maturity of two species of rajoid skates, genera Atlantoraja y Dipturus (Pisces, Elasmobranchii, Rajidae), from the south-western Atlantic Ocean. Journal of Applied Ichthyology, vol. 21, no. 1, p. 70-72.

PAESCH, L., 1999. Biomasa y rendimientos de los elasmobranquios: estructura de la población de Squalus acanthias, Squalus mitsukurii, Dipturus chilensis y Sympterygia bonapartii. In ARENA, G. and REY, M. (Eds.). Estudios realizados sobre los elasmobranquios dentro del Río de la Plata y la zona común de pesca Argentino-Uruguaya en el marco del "Plan de Investigación pesquera". Montevideo: INAPE; PNUD. URU/92/003.

PIRES, AMS., 1987. The contribution of isopods in the feeding of Sympterygia spp. (Pisces: Rajidae) with a description of Ancinus gaucho, new species (Isopoda: Sphaeromatidae). Boletim do Instituto Oceanografico de Sao Paulo, vol. 35, no. 2, p. $115-122$.

PRATT, HL., 1988. Elasmobranch gonad structure: a description and survey. Copeia, no. 3, p. 719-729.
PRESS, N., 1964 An unusual organelle in avian ovaries. Journal of Ultrastructural Research, vol. 10, no. 5-6, p. 528-546.

PRISCO, M., LOREDANA, R. and PIERO, A., 2002a. Ultrastructural studies on developing follicles of the spotted ray Torpedo marmorata. Molecular Reproduction and Development, vol. 61 , no. 1 , p. $78-86$.

PRISCO, M., RICCHIARI, L. and ANDREUCCETTI, P., 2001. An ultrastructural study of germ cells during ovarian differentiation in Torpedo marmorata. The Anatomical Record, vol. 263 , no. 3, p. 239-247.

PRISCO, M., ROMANO, M., RICCHIARI, L., LIMATOLA, E. and ANDREUCCETTI, P., 2002b. An ultrastructural study on the vitellogenesis in the spotted ray Torpedo marmorata. General and Comparative Endocrinology, vol. 128, no. 3, p. 171-179.

RAVAGLIA, MA. and MAGGESE, MC., 2003. Ovarian follicle ultrastructure in the teleost Synbranchus marmoratus (Bloch, 1795), with special reference to the vitelline envelope development. Tissue and Cell, vol. 35, no. 1, p. 9-17.

ROMERA, SA., 1993. Proleptus acutus (Nematoda: Physalopteridae), a parasite from the Argentinian skate, Sympterygia bonapartei (Pisces: Rajidae). Journal of Parasitology, vol. 79, no. 4, p. 620-623.

STEHMANN, MFW., 2002. Proposal of a maturity stages scale for oviparous and viviparous cartilaginous fishes (Pisces, Chondrichthyes). Archive of Fishery and Marine Research, vol. 50, no. 1, p. 23-48.

STORRIE, M., 2004. Microscopic modifications of the female reproductive tissues of Mustelus antarticus. Warrnambool: Deakin University. 153p. Tese de Doutorado.

TANZOLA, RD., GUAGLIARDO, SE., BRIZZOLA, SM., ARIAS, MV. and BOTTÉ, SE., 1998. Parasite assemblage of Sympterygia bonapartei (Pisces: Rajidae), an endemic skate of the southwest Atlantic. Helminthologia, vol. 35, no. 3, p. $123-129$.

TRICAS, TC., 1980. Courtship and mating-related behaviours in myliobatid rays. Copeia, no. 3, p. 553-556.

WEST, G., 1990. Methods of assessing ovarian development in fishes: a review. Australian Journal of Marine and Freshwater Researach, vol. 41, no. 2, p. 199-222. 
